\title{
CALL FOR ABSTRACTS ${ }^{\text {TH }}$ INTERNATIONAL CONFERENCE ON ETHICS EDUCATION October 3-5, 2018, Stellenbosch, South Africa A LONG WALK TO ETHICS EDUCATION
}

Published online: 18 September 2017

(C) Springer International Publishing AG 2017

The 6th International Conference on Ethics Education will take place in Stellenbosch, South Africa on October 3-5, 2018. The Conference is organized under the auspices of the International Association for Education in Ethics (https://www.ethicsassociation.org/). The main goals of the Association are the following: 1) to enhance and expand the teaching of ethics at national, regional and internationals levels; 2) to exchange and analyse experiences with the teaching of ethics in various educational settings; 3) to promote the development of knowledge and methods of ethics education; and 4) to function as a global centre of contact for experts in this field, and to promote contacts between members from countries around the world.

The conference theme "A long walk to ethics education" resonates with the autobiography of the iconic late President of South Africa, Dr. Nelson Rolihlahla Mandela. As such, the conference will focus on keynote addresses, various oral presentations and master class sessions that highlight and interrogate ethics education as a complex and dynamic process characterised by life-long perseverance, courage and integrity. In the last 10 to 15 years, South Africa has been very actively involved in offering a wide array of medical ethics and research ethics training courses on tertiary level, as well as various continuous professional development programmes in ethics for health professionals. In addition, there is a growing number of community leaders, politicians, Constitutional Court judges and academics from a wide variety of disciplines that recognise the importance of fostering ethics education skills amongst school educators and university lecturers in order to facilitate ethics awareness and ethics reasoning at all educational levels in South Africa and the Southern African Region.

\section{Abstracts will be welcomed on the following areas in ethics education:}

- Medical \& Health Sciences

- Research Ethics

- Law

- Art, Photography and Drama 
- Environmental Sciences, Agriculture, Animal / Wildlife Sciences

- Journalism, Social Sciences, Psychology and Theology (Religion)

- Sport

- Educational Insights

- Business and Management

- Engineering, Architecture and Nanotechnology

- ICT

\section{ABSTRACT SUBMISSION CLOSING DATE: 16 MARCH 2018}

Contact Prof Nico Nortje for more abstract information: abstracts@iaee6.com A Guide for Abstracts and information about the submission process is available at the Conference Web Site: www.iaee6.com 